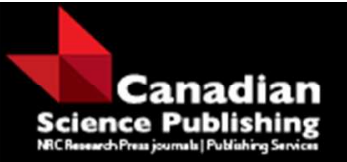

Canadian Journal of Forest Research Revue canadienne de recherche forestière

\title{
Species comparison of the physical properties of loblolly and slash pine wood and bark
}

\begin{tabular}{|r|l|}
\hline Journal: & Canadian Journal of Forest Research \\
\hline Manuscript ID & cjfr-2017-0091.R1 \\
\hline Danuscript Type: & Article \\
\hline Complete List of Authors: & $\begin{array}{l}\text { Eberhardt, Thomas; USDA Forest Service, Forest Products Laboratory } \\
\text { Dahlen, Joseph; University of Georgia, Warnell School of Forestry and } \\
\text { Natural Resources } \\
\text { Schimleck, Laurie; Oregon State University, College of Forestry }\end{array}$ \\
\hline Keyword: & bark thickness, southern pine, specific gravity, wood quality, yield \\
\hline $\begin{array}{r}\text { Is the invited manuscript for } \\
\text { consideration in a Special }\end{array}$ & N/A \\
Issue? : & \\
\hline &
\end{tabular}

SCHOLARONE ${ }^{\text {m }}$

Manuscripts 
3

$9{ }^{2}$ University of Georgia, Warnell School of Forestry and Natural Resources, 180 E Green

\section{SPECIES COMPARISON OF THE PHYSICAL PROPERTIES OF LOBLOLLY AND SLASH PINE WOOD AND BARK}

\author{
Thomas L. Eberhardt ${ }^{1 *}$, Joseph Dahlen ${ }^{2}$, Laurence Schimleck ${ }^{3}$
}

${ }^{1}$ USDA Forest Service, Forest Products Laboratory, One Gifford Pinchot Drive, Madison, WI 53726, USA; teberhardt@fs.fed.us

Street, Athens, GA 30602, USA; jdahlen@uga.edu

${ }^{3}$ Oregon State University, Wood Science and Engineering, 119 Richardson Hall, Corvallis, OR 97331, USA; Laurence.Schimleck@oregonstate.edu

14

5

(16)

17 *Corresponding Author: Thomas L. Eberhardt, Ph.D. USDA Forest Service Forest Products Laboratory One Gifford Pinchot Drive Madison, WI 53726, USA +16082319295 teberhardt@fs.fed.us 


\section{Abstract}

28 Composition of the southern pine forest is now predominated by two species, loblolly pine

29 (Pinus taeda L.) and slash pine (Pinus elliottii Engelm.), owing to fire suppression activities,

30 natural regeneration on abandoned agricultural lands, and extensive planting. Comparisons

31 of the wood and bark physical properties of these pines is of interest in terms of the yields of

32 usable biomass, and for the bark, its ecological functionality on a living tree. Trees from a

33 species comparison study were used to generate wood and bark property data, on a whole-

34 tree basis, and for stem disks collected at breast height. Models were constructed to explain

35 the effect of relative height on wood and bark properties. When comparing the whole-tree

36 data, slash pine wood (0.523 vs. 0.498$)$ and bark (0.368 vs. 0.311$)$ specific gravity values

37 were higher, both offset by lower moisture contents; slash pine, also produced a higher

38 percentage of bark on a dry-mass basis (17\% vs. $12.5 \%)$. Unlike wood properties, bark

39 properties showed significant between-species differences when determined at breast height

40 alone, the exception being moisture content. In terms of yield, harvests of a green tonne of

41 loblolly pine and slash pine would give approximately the same dry weight of wood, but

42 slash pine provides more bark.

44 Keywords: bark thickness, moisture content, specific gravity, wood quality, yield 


\section{Introduction}

The species composition of the pine forest of the southeastern United States has changed over the years, from the vast occurrence of longleaf pine (Pinus palustris Mill.) before colonial settlement, to the current predominance of loblolly pine (Pinus taeda L.),

51 favored by fire suppression activities and natural regeneration on abandoned agricultural

52 lands (Fox et al. 2007; Stanturf et al. 2002). Loblolly pine was previously relegated to wet

53 sites because of its susceptibility to fire when young, and was only a minor species on upland

54 sites dominated by longleaf pine and mixed hardwoods (Schultz 1999). Slash pine (Pinus elliottii Engelm.) accompanied longleaf pine along the lower coastal plain, but given its greater susceptibility to fire, this species was confined to wet sites too (Monk 1968).

Today, the ranges for both loblolly pine and slash pine have been expanded through extensive planting of seedlings from tree improvement programs (McKeand et al. 2003). In the southern region of the United States, loblolly and slash pines have been planted on more than 10 million ha and 4.2 million ha, respectively (Barnett and Sheffield 2004; Huggett et al. 2013; Wear and Greis 2012). Loblolly pine is generally favored because of its rapid growth, ability to grow well on a range of sites, and resistance to fusiform rust; thus, loblolly pine comprises more than one half of the total southern pine volume (Schultz 1999; Shiver et al. 2000).

Side-by-side studies conducted to compare loblolly and slash pines have led to the general conclusion that loblolly pine productivity is higher, the exception being on very poorly drained flatwood sites (Borders and Harrison 1989). For example, Shiver et al. (2000)

68 found that loblolly pine had significantly greater total stand volume (130 vs. $\left.120 \mathrm{~m}^{3} \mathrm{ha}^{-1}\right)$ and

69 total green weight per hectare (119 vs. 105 tonnes $\mathrm{ha}^{-1}$ ) than slash pine when grown on the

70 same site at age 14. Other comparisons of these two species have been extensive and include

71 biomass allocation patterns (e.g., foliage, branch, and stem mass), physiological responses 
72 (e.g., stomatal conductance, photosynthesis), and productivity (e.g., aboveground biomass)

73 determinations (Burkes et al. 2003; Chmura et al. 2007; Chmura and Tjoelker 2008; Colbert

74 et al. 1990; Dalla-Tea and Jokela 1991; Gonzalez-Benecke et al. 2014; Jokela and Martin

75 2000; Roth et al. 2007; Samuelson et al. 2012; Vogel et al. 2011).

76 Wood properties for loblolly and slash pines, such as specific gravity (SG), are readily

77 available in the literature, and in some instances reflect mean values based on large pools of

78 accumulated historical data (e.g., Forest Products laboratory 2010); the caveat when making

79 general comparisons of data from individual studies found in the literature is that geographic

80 location has a significant influence on SG (Clark and Saucier 1991; Jordan et al. 2008).

81 Therefore, when comparisons of wood properties for loblolly pine and slash pine are made,

82 there is greater confidence in the significance of observed differences when trees from the

83 same geographic region are used. Altogether, data in the literature show that the SG of slash

84 pine is higher than that for loblolly pine (Clark and Saucier 1991; Cole et al. 1966; Phillips et

85 al. 1976). Recent determinations of basic SG for these two southern pines by X-ray

86 densitometry of wood cores showed the whole-core values for slash pine (0.65) to be higher

87 than those for loblolly pine (0.61), with notable differences in the SG of juvenile wood

88 (Eberhardt and Samuelson 2015). Since the trees used in this study were mature (50 years),

89 the cores were solvent extracted to remove the contribution of heartwood extractives to the

90 SG and scanned again; results showed the same trend in SG, save for slightly lower whole-

91 core values (slash pine $=0.63$, loblolly pine $=0.58$ ). The difference in ring SG would appear

92 to derive from the greater proportion of latewood in slash pine $(68 \%)$ compared to loblolly

93 pine (61\%) given that the earlywood SG of slash pine (0.36) and loblolly pine (0.35) are

94 similar and the latewood SG of slash pine (0.78) and loblolly pine (0.77) are also similar

95 (Eberhardt and Samuelson 2015). 
96 Lacking in the literature are comparisons of the bark from these two southern pine

97 species that would be of interest in terms of both the ecological functionality on a living tree

98 (e.g., resistance to fire) and yields of usable biomass. Indeed, for some southern pine species,

99 characterizations of the bark are relatively uncommon with detailed measurements of

100 longleaf pine bark (e.g., thicknesses of the inner bark (secondary phloem) and outer bark

101 (rhytidome) layers (Eberhardt 2013), and values for bark roughness (Eberhardt 2015)) only

102 recently being reported. Whole bark thicknesses, which are often determined from wood disk

103 diameter measurements outside the bark, subtracting those determined inside the bark, were

104 used to estimate bark volumes of disks taken along the bole for loblolly pine (Antony et al.

105 2015). Alternatively, bark thickness gauges have seen use in field studies involving southern

106 pines, such as species comparisons (Dipesh et al. 2015) and assessments of the functionality

107 of bark against insects (Hanula et al. 2000) and fire (Wang and Wangen 2011); note that the

108 quality of the data from bark gauges is highly dependent upon the skill level of the operator

109 (Laasasenaho et al. 2005).

110 Given the development of wood-bioenergy markets, there is increasing interest in

111 determining bark quantities as a subset of above-ground biomass determinations. The yield

112 of bark (on a dry-weight basis) from southern pines collectively is a little more than $10 \%$

113 along the bole (Cole et al. 1966) with up to 60\% for small longleaf pine branches (Phillips et

114 al. 1976). Specific to slash pine and loblolly pine, a recent biofuels study showed that slash

115 pine had a higher bark content (14.1\%) than loblolly pine (10.5\%), determined by hand-

116 sorting the material obtained following whole-tree chipping (Baker et al. 2012); note that

117 these values provide only a relative comparison because only larger particles of wood and

118 bark were partitioned, and since the moisture content (MC) of the bark was not determined, it

119 is not possible to estimate any differences on a dry-weight basis. Likewise, bark fuel value

120 data (SG, higher heating value) seem to suggest higher values for slash pine, but the source of 
121 the bark was not reported and there was no statistical assessment of species differences

122 (Harder and Einspahr 1976). In a recent report by Antony et al. (2015), bark measures

123 including its percentage of the tree stem, SG, and MC were determined for loblolly pine for

124 different physiographic regions as part of an extensive sampling program orchestrated

125 through the Wood Quality Consortium led by the University of Georgia. The objective of the

126 current study was to compare wood and bark physical property data from stands of loblolly

127 pine and slash pine, grown on the same site within the South Atlantic Coastal Plain;

128 measurements along the bole provide the most comprehensive between-species comparison

129 to date. Data presented here are relevant to the development of a better understanding of the

130 ecological functionality of bark in a southern pine forest ecosystem and physical properties

131 impacting the utilization of a southern forest biomass resource.

132

133 2. Materials and methods

134 2.1. Trees used in study

135 Ten plantations were sampled, ages 21 to 24 years, from a species comparison study

136 established by the University of Georgia Pine Management Research Cooperative with the

137 objective being to quantify growth differences between loblolly pine and slash pine when

138 grown on the same site (Shiver et al. 2000). The ten stands were located in the South Atlantic

139 Coastal Plain (Georgia and Florida). The stand locations are shown in Figure 1; note that

140 stands 1 and 2 were located next to each other and share the same latitude and longitude

141 (Table 1). The loblolly pine trees were included in the Wood Quality Consortium baseline

142 study looking at regional differences in loblolly pine SG (Jordan et al. 2008). The plantations

143 were conventionally managed with the exception of site preparation, the planting density was

144 approximately 1,779 trees per ha, and the trees were thinned following age 14 . Table 1 
145 shows the summary statistics for the stands with location, age, DBH, and height for the two 146 pine species.

147

\subsection{Tree sampling and bark measurements}

149 Three trees from each species were felled from each of the 10 stands with one felled

150 tree representing the mean diameter class from the stand (the diameter class being determined

151 in $25 \mathrm{~mm}$ intervals). The other two felled trees were selected as representing diameter classes

152 that were immediately above and below the mean diameter class. Trees were felled with a

153 chainsaw, their branches removed, and the total height of the main bole recorded. Cross-

154 sectional disks (3.8 cm thickness) were collected along the tree at 0.15 and $1.4 \mathrm{~m}$ (or $1.5 \mathrm{~m})$

155 from the base and then at $1.5 \mathrm{~m}$ intervals up to an outside bark diameter of $5 \mathrm{~cm}$. Disks were

156 sealed in plastic bags and transported back to the laboratory for further processing. Outside

157 and inside bark diameters were measured for the green disks with the difference providing a

158 measure of double bark thickness. Green weights were determined for the intact disks and

159 the peeled wood disks, the latter prepared by carefully peeling the bark away with the aid of a

160 chisel; the green weight of the bark was determined from the difference in green weight for

161 the intact disk and the corresponding peeled wood disk. Basic SG of bark and wood were

162 based on the oven-dry weights and green volumes; the largest section of peeled bark used to

163 determine the value for bark. Oven drying was carried out at $103 \pm 2{ }^{\circ} \mathrm{C}$ until a constant

164 mass was achieved (ASTM 2014). Green volumes were determined on the separated wood

165 and bark components by water immersion after soaking in water to ensure full saturation.

166 Moisture contents were based on green and oven-dry weights of the wood and bark

167 components, and reported on a dry weight basis as done in Antony et al. (2015). The

168 percentage of bark was calculated on the basis of the oven-dry weights of the bark and wood. 169 


\subsection{Statistical analysis and tree reconstruction}

The statistical analysis and associated graphics were done in $\mathrm{R}$ statistical software $(\mathrm{R}$ Core Team 2016) with RStudio interface (RStudio 2016) and the packages dplyr (Wickham and Francois 2016), ggmap (Kahle and Wickham 2013), and lmerTest (Kuznetsova et al. 2016). The disk measurements were used to reconstruct an estimate of the whole-tree bark properties using the dplyr package (Wickham and Francois 2016) within R (R Core Team 2016). For each tree, the area of the wood and bark were calculated for each disk, and the wood and bark properties then weighted on the basis of these individual disk areas, relative to the total area for all disks, to find the whole-tree properties. The proportions of bark were determined on both a weight basis and a green volume basis; note that the southern pines are typically bought and sold on a weight basis, thus weight basis is more applicable to the forest industry sector.

The mean, standard deviation, and range of the values were calculated for each variable. For the wood, the SG, MC, and green weight were calculated. For the bark, the double bark thickness, SG, MC, green weight, percent of dry mass, and percent of green volume were calculated. For the wood and bark, the green weight of wood and bark to volume of wood, and the green weight of wood and bark to volume of wood and bark were calculated. Analysis of variance was conducted using linear mixed-effects models to test the effect of species on the wood properties with stand and tree as random factors. A 0.05 significance level was used for all statistical tests. Models were developed by examining the plots and determining the general relationship between the dependent and independent variables; when nonlinear trends were found, the nonlinear model forms used were those discussed in Ratkowsky (1990). The regression models were evaluated by examining the plots and determining if the parametrized model fit to the general trend of the data. The coefficient of determination $\left(\mathrm{R}^{2}\right)$, based on the relationship between the actual variable and 
195 the predicted variable, was calculated, as was the root mean square error (RMSE). Linear

196 models were constructed to explain the relationship between wood MC and wood SG:

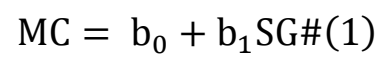

where $b_{0}$ and $b_{1}$ are the regression model parameters. Quadratic and nonlinear models were constructed to explain the effect of wood properties by relative height. A quadratic model was used to explain the relationship between bark SG, or bark percentage, with relative height:

$$
\mathrm{y}=\mathrm{b}_{0}+\mathrm{b}_{1} \mathrm{rh}+\mathrm{b}_{2} \mathrm{rh}^{2} \#(2)
$$

where $y$ is bark SG or bark percentage, rh is relative height, and $b_{0}, b_{1}, b_{2}$ are the regression parameters. For the wood SG models, a nonlinear model was used:

$$
\mathrm{y}=\mathrm{b}_{0}+\mathrm{b}_{1} * \log \left(\mathrm{rh}^{-\mathrm{b}_{2}}-1\right) \#(3)
$$

204 where y is wood SG, rh is relative height, and $b_{0}, b_{1}, b_{2}$ are the regression parameters. For wood MC models, a nonlinear model was used:

$$
y=\frac{\mathrm{b}_{0}}{1+e^{\frac{\mathrm{b}_{1}-r h}{\mathrm{~b}_{2}}} \#(4)}
$$

where $\mathrm{y}$ is wood $\mathrm{MC}$, rh is relative height, and $\mathrm{b}_{0}, \mathrm{~b}_{1}, \mathrm{~b}_{2}$ are the regression parameters. For the bark MC models, a nonlinear model was used:

$$
\mathrm{y}=e^{\mathrm{b}_{0}+\mathrm{b}_{1} r h+\mathrm{b}_{2} r h^{2}} \#(5)
$$

where $\mathrm{y}$ is bark $\mathrm{MC}$, rh is relative height, and $\mathrm{b}_{0}, \mathrm{~b}_{1}, \mathrm{~b}_{2}$ are the regression parameters.

\section{Results}

\subsection{Wood properties}

\subsubsection{Wood $S G$}

The whole-tree values determined for wood SG showed a significant difference $(P=$

$2150.0001)$ between loblolly and slash pines, with the value for slash pine (0.523) being higher 
216 than that for loblolly pine (0.498). Stand level data were also generated (Table 3) and

217 showed higher values for wood SG in slash pine compared to loblolly pine for all but one

218 stand. Since many studies rely on the sampling of tree cores collected at breast height alone,

219 the data were processed accordingly for comparative purposes. In contrast to the whole-tree

220 values discussed above, no significant difference $(P=0.1151)$ was observed between loblolly

221 and slash pines for the breast height alone values (Table 4); no trends were observed in the

222 corresponding stand-level data (Table 5). We attribute the higher wood SG values at breast

223 height (loblolly pine $=0.557$; slash pine $=0.570$ ), relative to the whole-tree values, to the

224 presence of mature wood that decreases in its contribution to total stem wood (juvenile and

225 mature wood) with increasing tree height. Plotting wood SG for all disks against relative

226 height shows wood SG to decrease for both species with relative height up the tree, and wood

227 SG data points for slash pine trending higher than those for loblolly pine (Figure 2a).

228 Nonlinear models were constructed to explain wood SG based on relative height. The

229 model for loblolly pine is:

230

Loblolly Pine Wood SG $=0.472+0.036 * \log \left(r h^{-0.683}-1\right) \#(6)$

231 where $\mathrm{rh}$ is the relative height. The $\mathrm{R}^{2}$ was 0.77 for the model with a RMSE of 0.027 . The

232 model for slash pine is:

233

$$
\text { Slash Pine Wood } S G=0.496+0.027 * \log \left(r h^{-0.788}-1\right) \#(7)
$$

234 where rh is relative height. The $\mathrm{R}^{2}$ was 0.60 for the model with a RMSE of 0.034 . A

235 comparison of the two models reveals that the inflection point for the slash pine model

236 (0.496) is higher than loblolly pine (0.472).

237

238 3.1.2. $\operatorname{Wood} M C$ 
Wood MC determined on a whole-tree basis also showed a significant difference $(P<$ $0.0001)$, with the value for loblolly pine (106\%) being higher than slash pine (96\%). Standlevel data were also generated (Table 3) and show higher wood MC in loblolly pine, compared to slash pine, for all stands. The higher MC for wood with lower SG is consistent with the theoretical maximum $\mathrm{MC}\left(\mathrm{MC}_{\max }\right)$ calculation for wood:

$$
M C_{\text {Max }}=\frac{1}{S G_{g}}-\frac{1}{1.54} \#(8)
$$

where $\mathrm{SG}_{\mathrm{g}}$ is the green $\mathrm{SG}$, and 1.54 is the $\mathrm{SG}$ of the cell wall (Forest Products Laboratory 2010). Thus, within a species, lower SG wood tends to have a higher MC. The relationship between wood MC with wood SG was linear for both species. The model for loblolly pine is:

$$
\text { Loblolly Pine Wood MC = 326-440SG\#(9) }
$$

where the $\mathrm{R}^{2}$ was 0.90 for the model with a RMSE of $9 \%$. The model for slash pine is:

$$
\text { Slash Pine Wood MC }=308-403 S G \#(10)
$$

where the $\mathrm{R}^{2}$ was 0.87 for the model with a RMSE of $8 \%$.

In contrast to the whole-tree values for wood $\mathrm{MC}$, no significant difference $(P=$ 0.2576) was observed between loblolly and slash pines for the breast-height values (Table 4); and no trends were observed in the corresponding stand-level data (Table 5). The lack of significant differences in MC mirrors the lack of differences in SG at breast height. We attribute the lower wood MC values at breast height (loblolly pine $=80 \%$; slash pine $=77 \%$ ), relative to the whole-tree values, to the presence of mature wood that decreases in its contribution to total stem wood (juvenile and mature wood) with increasing tree height.

Plotting wood MC for all disks against relative height shows wood MC for both species increases with relative height up the tree, with wood MC for slash pine being consistently lower than that for loblolly pine (Figure $2 \mathrm{~b}$ ). Data points for loblolly pine were 
261 model was constructed for wood MC as a function of relative height. The model for loblolly

262 pine is:

263

$$
\text { Loblolly Pine Wood MC }=\frac{150}{1+e^{\frac{0.017-r h}{0.239}}} \#(11)
$$

264 where rh is relative height. The $\mathrm{R}^{2}$ was 0.77 for the model with a RMSE of $13 \%$. The model 265 for slash pine is:

$$
\text { Slash Pine Wood MC }=\frac{144}{1+e^{\frac{-0.00574-r h}{0.354}}} \#(12)
$$

267 where rh is relative height. The $\mathrm{R}^{2}$ was 0.71 for the model with a RMSE of $12 \%$. The asymptote parameter is slightly higher for loblolly pine (150\%) than slash pine (144\%) indicating that at the tops of the trees the MC will be higher for loblolly pine than slash pine.

\subsection{Bark properties}

272

273

274

275

276

277

278

279

280

281 282

\subsubsection{Bark $S G$}

Data collected through the present study also provided the opportunity to directly compare bark properties for loblolly and slash pines on a whole-tree basis. Whole-tree bark SG for slash pine was significantly higher $(0.368$ vs. $0.311, P<0.0001)$ than for loblolly pine (Table 2). Stand-level data were also generated (Table 3) and for all stands slash pine had higher bark SG than loblolly pine. Similar to the whole-tree values for bark SG, a significant difference $(P<0.0001)$ was observed between loblolly pine $(0.295)$ and slash pine $(0.364)$ for the samples collected at breast-height (Table 4); the corresponding stand-level data showed consistently higher values for slash pine relative to loblolly pine (Table 5). Bark SG values for both species were only slightly lower at breast height, relative to the whole-tree values. 

than those for loblolly pine (Figure 3a). Simple linear correlation coefficients were essentially zero (not shown). Quadratic models were constructed for bark SG. The loblolly pine model is:

$$
\text { Loblolly Pine Bark } S G=0.291+0.218 r h-0.256 r h^{2} \#(13)
$$

where rh is relative height. The $\mathrm{R}^{2}$ was 0.18 for the model with a RMSE of 0.034 . The slash

$$
\text { Slash Pine Bark SG }=0.366+0.026 r h-0.042 r h^{2} \#(14)
$$
loblolly pine was much more pronounced than what was found for slash pine.

\subsubsection{Bark $M C$}

Bark MC determined on a whole-tree basis also showed a significant difference $(P=$

0.0007), with the value for loblolly pine (78\%) being higher than that for slash pine $(69 \%)$.

While there were strong linear relationships between wood SG and MC, the bark relationships were neither apparent for loblolly pine $\left(\mathrm{R}^{2}=0.03\right)$ nor slash pine $\left(\mathrm{R}^{2}=0.18\right)$. In contrast to the whole-tree values for bark MC, no significant difference $(P=0.8245)$ was observed between loblolly pine (52\%) and slash pine (53\%) for the breast-height values

302 (Table 4); likewise, while the stand-level data showed mostly higher values for loblolly pine relative to slash pine for the whole-tree data (Table 3), this was not apparent for the breastheight alone data (Table 5). Plotting bark MC for all disks against relative height (Figure 3b) clearly shows increases with relative height up the tree, similar to that for wood (Figure 2b); however, the bark MC data diverge to a greater extent with height than observed for wood the 
307 MC data. Plotting bark MC against wood MC showed weak linear correlations for both

308 loblolly pine $\left(\mathrm{R}^{2}=0.51\right)$ and slash pine $\left(\mathrm{R}^{2}=0.44\right)$ (plots not shown).

309 Nonlinear models were constructed for bark MC. The loblolly pine model is:

$$
\text { Loblolly Pine Bark MC }=e^{3.879+2.382 r h-0.892 r h^{2}} \#(15)
$$

311 where rh is relative height. The $\mathrm{R}^{2}$ was 0.66 for the model with a RMSE of $33 \%$. The slash

312 pine model is:

$$
\text { Slash Pine Bark MC }=e^{3.864+1.6 r h-0.505 r h^{2}} \#(16)
$$

314 where rh is relative height. The $\mathrm{R}^{2}$ was 0.49 for the model with a RMSE of $27 \%$. The model

315 starting points are similar (3.879 vs. 3.864$)$ but the parameters allow separation as relative

316 height increases.

317

\subsubsection{Bark percentages and thickness}

319 The whole-tree values determined for bark percentage on a dry-mass basis (Table 2)

320 showed a significant difference $(P<0.0001)$ between loblolly and slash pines, with the value

321 for slash pine (17.0\%) being higher than that for loblolly pine (12.5\%); results on a dry-

322 weight basis are common to biomass allocation studies (e.g., Phillips et al. 1976). Parallel

323 results were obtained on data based on green bark volumes. Plotting the bark percentage

324 values (dry-mass basis) against relative height showed that for loblolly pine the values at the

325 base of the tree and at the top of the tree were above $10 \%$, offset by some values at mid-

326 height being lower than 10\% (Figure 4); bark percentage values for slash pine trended in a

327 similar manner except for being shifted roughly 5 percentage points higher.

328 Quadratic models were constructed for bark percentages (dry-mass basis). The

329 loblolly pine model is: 


$$
\text { Loblolly Pine Bark \% = } 15.883-25.175 r h+24.735 r h^{2} \#(17)
$$

330 where rh is relative height. The $\mathrm{R}^{2}$ was 0.27 for the model with a RMSE of $3.1 \%$. The slash

331 pine model is:

$$
\text { Slash Pine Bark \% = } 20.307-32.647 r h+42.392 r h^{2} \#(18)
$$

332 where rh is relative height. The $\mathrm{R}^{2}$ was 0.33 for the model with a RMSE of $4.2 \%$.

333 In the current study, no difference in double bark thickness was observed for loblolly

334 pine and slash pine on a whole-tree basis $(P=0.7148)$ or at breast height $(P=$

335 0.1896). However, given that bark thickness is influenced by tree diameter a more

336 appropriate comparison is the volume of bark of which slash pine had significantly higher

337 green volume $(P=<0.0001,22.5 \%$ vs. $18.7 \%)$.

\subsection{Green weights of wood and bark}

340 The green weight of wood $\left(\mathrm{kg} \mathrm{m}^{-3}\right)$ was determined on both a whole-tree basis (Table

2) and at breast height alone (Table 4). No significant differences (whole tree, $P=0.6425$;

breast-height, $P=0.4960$ ) were observed in either case for green weight of wood between the

two species. The whole-tree green weight of bark was also determined (Table 2) and found

to be higher $(P<0.0001)$ for slash pine $\left(619 \mathrm{~kg} \mathrm{~m}^{-3}\right)$ than for loblolly pine $\left(553 \mathrm{~kg} \mathrm{~m}^{-3}\right)$.

Similar results were obtained with the breast-height green weight values (Table 4) with the

value for slash pine $\left(554 \mathrm{~kg} \mathrm{~m}^{-3}\right)$ being significantly higher $(P<0.0001)$ than that for loblolly

347 pine $\left(448 \mathrm{~kg} \mathrm{~m}^{-3}\right)$.

Another related measure is the green weight of wood and bark to the volume of wood

(Miles and Smith 2009), a measure most commonly used for scaling logs manually. Here we found significant differences $(P<0.0001)$ with slash pine $\left(1202 \mathrm{~kg} \mathrm{~m}^{-3}\right)$ having higher green weight than loblolly pine $\left(1151 \mathrm{~kg} \mathrm{~m}^{-3}\right)$. Alternatively, the green weight of wood and bark can be reported using the combined volume of wood and bark which is likely more 
353

354

355

356

357

358

359

360

361

362

363

364

365

366

367

368

369

370

371

372

373

374

375

376

377

appropriate for the southern pines which are sold on the basis of weight. We did not find significant differences when using the green volume of wood and bark $(P=0.5041)$. The whole-tree and breast-height data are provided in Tables 2 and 4, respectively, given that they have a practical application for wood sales.

\section{Discussion}

\subsection{Wood physical property differences}

The higher whole-tree wood SG value for slash pine, compared to loblolly pine, is consistent with literature reports (Harder and Einspahr 1976; Clark and Saucier 1991; Forest Products Laboratory 2010). Unique to the current study is that we demonstrate a statistically significant difference for trees of similar age, diameter, and height, with all trees sampled being within the same physiographic region. In a prior study comparing only loblolly pine in 6 physiographic regions, significant differences in whole-tree wood SG were observed between some of the regions (Antony et al. 2015); likewise, significant differences between some of the physiographic regions were observed with whole-core wood SG values determined at breast height alone (Jordan et al. 2008). The consequences of including additional physiographic regions (and/or age classes) in the current study are not known; the number of physiographic regions in any such assessment would be limited by the fact that the range for slash pine is not as widespread as it is for loblolly pine. Among the physiographic regions encompassed in the range of slash pine, results are conflicting with Antony et al. (2015) observing differences in loblolly pine whole-tree wood SG as opposed to Jordan et al. (2008) not observing differences using whole-disk data determined at breast height alone.

Given the potential for the data variability to be impacted by sampling from different physiographic regions, it is plausible that the statistically significant between-species difference we demonstrate here may not occur in other physiographic regions. 
Wood MC determined on a whole-tree basis was higher for loblolly pine (106\%) than slash pine (96\%), similar to the findings of Baker et al. (2012) who reported a significant difference for the MC of loblolly pine and slash pine chips (110 vs. 103\%, $P=0.004)$.

Within a species, lower SG wood tends to have a higher MC. This trend was observed in a study examining the regional differences in wood properties of loblolly pine (Antony et al. 2015), where the inverse relationship between wood SG and MC is accentuated with lower values for wood SG $(0.423-0.468)$ than those reported here, coinciding with higher values for wood MC on a dry-weight basis (109-128\%).

\subsection{Bark physical property differences}

Whole-tree bark SG for slash pine was higher (0.368 vs. 0.311) than for loblolly pine, similar to values in the literature ( 0.373 vs. 0.329$)$, albeit these volume-weighted values were reported with no statistical comparison (Phillips et al. 1976). Higher bark SG was reported for slash pine (0.474) and loblolly pine (0.477) by Martin (1969), with those values being even higher than the maximums we observed for slash pine (0.412) and loblolly pine (0.365). It should be noted that the values determined by Martin (1969) were based on an oven-dry basis (oven-dry weight and oven-dry volume) and not a green basis (i.e., oven-dry weight and green volume) as done in the present study. We can attribute these higher bark density values to a significantly lower volume for dry bark relative to green bark. Specifically, in a study on longleaf pine bark, it was found that radial shrinkage for the inner bark on the northern face of the tree was nearly $23 \%$ upon drying green bark under ambient conditions (Eberhardt 2013); the corresponding value for the outer bark was nearly $13 \%$. With bark samples used by Martin (1969) being in an oven-dry state, significantly lower volumes would have resulted

401 in significantly higher bark SG values. Similar to the whole-tree values for bark SG, a

402 significant difference was observed between loblolly pine (0.295) and slash pine (0.364) for 
the samples collected at breast-height. Bark SG values for both species were only slightly

404 lower at breast height, relative to the whole-tree values.

405 Consistent with the above results, plotting bark SG against relative height (Figure 3)

406 showed the data for slash pine trend higher than those for loblolly pine, with maximums near

407 mid-height for both species. The exact reason for the bark SG values to show maximums as

408 such may be the result of bark anatomy related to the proportions of living inner bark

409 (functional phloem) and essentially dead outer bark (rhytidome) along the length of the tree

410 bole; the inner bark transports the products of photosynthesis while the outer bark seals in

411 moisture and provides a protective barrier (Eberhardt 2013, 2015; Trockenbrodt 1990). In

412 very simplified terms, the development of new periderms results in the oldest zones of inner

413 bark being transformed into an ultimately dead layer in the outer bark. The layers in outer

414 bark differ from xylem in that they are not specifically formed annual layers, nor do they all

415 remain for the life of the tree, with the outermost layers of outer bark sloughed off with time

416 (Eberhardt 2013). Moving up from the base of the tree, the proportion of outer bark

417 decreases, as does the degree of weathering. It is plausible that the SG of the outer bark

418 decreases upon weathering, thereby reversing the trend of increasing SG with increasing

419 outer bark thickness. Further work is needed to determine the SG of the inner and outer bark

420 components, and the impact of aging on bark SG, to validate this rationalization of the

421 aforementioned mid-height maximums in bark SG.

422 Bark MC determined on a whole-tree basis gave a higher value for loblolly pine

$423(78 \%)$ compared to slash pine (69\%). Slightly lower values were reported by Phillips et al.

424 (1976) for loblolly pine (65\%) and slash pine (52\%). Following the same inverse relationship

425 between wood MC and wood SG, a higher bark MC coincided with a lower bark SG. In

426 general terms, this inverse relationship was reported for loblolly pine (Antony et al. 2015)

427 when making side-by-side comparisons of bark MC and bark SG data for different 
428 physiographic regions. The data reported by Phillips et al. (1976) showed the inverse to hold

429 true when comparing the data for slash pine and loblolly pine, but not necessarily the other 430 two southern pines (longleaf pine, shortleaf pine) included in that study.

431 As discussed above, bark is comprised of inner and outer bark components with 432 differences in anatomy, state of living, and functionality. Specific to the MC of inner and 433 outer bark components, Reifsnyder et al. (1967) determined average values for red pine 434 (Pinus resinosa Ait.), on a dry-weight basis, to be $182 \%$ for the inner bark and $25 \%$ for the 435 outer bark. This led to the conclusion that determinations of bark MC are "strongly influenced" by the inner and outer bark proportions. In longleaf pine, the thickness of the inner bark is relatively constant while that for the outer bark declines from the base of the tree upwards (Eberhardt 2013; 2015). It is likely that the two southern pines in this study have similar distributions of inner to outer bark, thus the increase in bark MC with relative height can be attributed to an increasing proportion of inner bark.

\subsection{Bark percentages and yields}

The whole-tree values determined for bark percentage on a dry-mass basis showed the value for slash pine (17.0\%) being higher than that for loblolly pine (12.5\%); Phillips et al. (1976) also observed the percentage of bark, determined on a dry-weight basis, to be higher in slash pine relative to loblolly pine. Specifically, the values were 1.4 percentage points higher for slash pine (12.7\%) relative to loblolly pine (11.3\%) in the stem and 11.3 percentage points higher in the branches (32.5\% vs. $21.2 \%)$. Baker et al. (2012) also compared loblolly and slash pines and found the percentage of bark, on a wet-weight basis, to be 3.6 percentage points higher for slash pine (14.1\%) compared to loblolly pine $(10.5 \%)$.

451 Plotting the bark percentage values against relative height (Figure 4) showed loblolly pine 452 and slash pine trended in a similar manner except for the values for slash pine being shifted 
roughly 5 percentage points higher. In terms of utilization, slash pine would provide a higher

454 amount of bark residue, irrespective of where the roundwood is taken (i.e., butt log, tree 455 tops).

\subsection{Fire ecology of thicker bark} on a whole-tree basis or at breast height. In terms of its adaptation to the environment, it has

460 been widely hypothesized that thicker bark is a response to more frequent fires (e.g., Pausas 2015). Of the southern pines, longleaf pine, which previously dominated forests in the southeastern United States, is considered a fire climax species and displays a number of adaptations (thick bark, grass stage) that allow it to tolerate frequent, low-intensity fires can tolerate fire to some degree but are not as resistant as longleaf pine (Hardin et al. 2001); while south Florida slash pine (Pinus elliottii var. densa Little and Dorman) display adaptions similar to longleaf pine (Hardin et al. 2001; Menges and Deyrup 2001). The important role of thick bark in surviving fire was demonstrated by Hare (1965) who exposed the bark of standing loblolly and slash pine trees to a flame and reported significantly longer times for the cambium of slash pine trees to reach $140^{\circ} \mathrm{C}$ than for loblolly pine (Hare 1965). Since the thermal conductivity of bark is a function of its density, MC, and temperature (Bauer et al. 2010; Martin 1963), it may not be appropriate to attribute fire resistance to any single attribute. Hare (1965) did not measure bark density or MC. from the cambium it is protecting. Determinations of bark "roughness" of longleaf pine 
wood disks were only recently conducted by measuring maximum and minimum bark thicknesses and showed bark roughness values to be constant to a relative height of $60 \%$, decreasing up through the crown (Eberhardt 2015). It was beyond the scope of the current study to conduct such measurements; however, we can say that since bark structure (appearance) varies among the southern pines, and it roughness varies along the stem for a given species, that fire resistance cannot be simply attributed to the thickness (or percent of dry mass or percent of green volume) of bark for any given species.

\subsection{Green weights and roundwood processing}

Roundwood is frequently sold on the basis of its "green weight," a value with units of weight and volume, being pounds per cubic foot or kilograms per cubic meter (Miles and Smith 2009). Along with results for SG and MC, Anthony et al. (2014) reported green weights for wood. Parallel to that study, the green weight of wood $\left(\mathrm{kg} \mathrm{m}^{-3}\right)$ was determined on both a whole-tree basis and at breast height alone, with no significant between-species differences. These results can be rationalized by the higher wood SG for slash pine being offset by lower wood MC, relative to the corresponding values for loblolly pine. Intuitively, with similar green weights, costs associated with the transportation of green wood should be the same for both species, especially after debarking, as done for pulp-grade chips produced during lumber manufacturing. The mill buying the chips would receive more wood with slash pine given the higher SG and lower MC; however, these values are taken for the whole tree and do not reflect the outer portion of the bole which is where these chips are typically produced.

The whole-tree green weight of bark was determined to be higher for slash pine (619 $\mathrm{kg} \mathrm{m}^{-3}$ ) compared for loblolly pine $\left(553 \mathrm{~kg} \mathrm{~m}^{-3}\right)$; similar results were obtained with the breast-height green weight values. Only very limited data are available that specify the MC 
503 of the inner and outer bark components. Reifsnyder et al. (1967) determined average values

504 for red pine MC, on a dry-weight basis, to be $182 \%$ for the inner bark and $25 \%$ for the outer

505 bark; similar results were reported by Martin (1969) for loblolly, longleaf, and slash pines.

506 Accordingly, the MC of a whole bark sample is a reflection of the proportions of inner bark

507 and outer bark. We can attribute the higher whole-tree green weight of bark to the increasing

508 proportion of higher MC inner bark with increasing relative height. Since prior work has

509 shown that the proportions of inner and outer bark present in bark residues obtained during

510 industrial processing is dependent up the debarking method applied (Eberhardt 2012),

511 transportation costs based on weight may be subtly impacted by pine species composition and

512 compounded by how the roundwood was processed.

513 Using the values found here, a tonne $(1000 \mathrm{~kg})$ of green loblolly pine wood and bark

514 would produce $494 \mathrm{~kg}$ of dry biomass of which $432 \mathrm{~kg}$ would be wood and $62 \mathrm{~kg}$ would be

515 bark. A tonne of green slash pine wood and bark would produce $522 \mathrm{~kg}$ of dry biomass of

516 which $433 \mathrm{~kg}$ would be wood and $89 \mathrm{~kg}$ would be bark. Thus a tonne would yield essentially

517 the same weight of wood but the slash pine tonne would result in more bark. It is important

518 to note that these samples were collected in the summer months from May to August, and

519 thus variation is likely to be found if these same stands were to be sampled in different

520 seasons. Doruska and Patterson (2006) found that loblolly pine significantly varied with the

521 highest weight scaling factors found in the spring and fall months compared to the summer

522 and winter months. It is also important to note that the wood/bark SG and MC of different

523 age trees and different silvicultural treatments will yield different values.

525 5. Summary

526 The destructive sampling of trees from a species comparison study provided wood

527 property data for loblolly pine and slash pine showing differences on a whole-tree basis, but 
528 not for disks collected at breast height alone. Particularly unique to this study was the

529 parallel collection of bark property data that are of interest in terms of both ecological

530 functionality and biomass yields. Whole-tree bark SG was significantly higher for slash pine

531 offset by the bark MC being significantly higher for loblolly pine; the percentage of bark for

532 slash pine was significantly higher than that for loblolly pine. Unlike the wood properties,

533 bark properties showed significant between-species differences when determined at breast

534 height alone, the exception being MC. Altogether, results demonstrate that a harvest of

535 loblolly pine and slash pine would yield the same weights of dry wood; however, slash pine

536 would yield more bark, irrespective of harvesting location. Higher processing costs would be

537 associated with drying the additional moisture in loblolly pine wood compared to that in slash

538 pine wood. Also, facilities that utilize the bark for generating energy would also have greater

539 energy yields from slash pine than from loblolly pine.

\section{References}

Antony, F., Schimleck, L.R., Daniels, R.F., Clark III, A., Border, B.E., Kane, M.B., and

Burkhart, H.E. 2015. Whole-tree bark and wood properties of loblolly pine from intensively managed plantations. For. Sci. 61(1): 55-66.

ASTM International. 2014. Standard test methods for density and specific gravity (relative density) of wood and wood-based materials. West Conshohocken, PA.

Baker, S.A., Green, W.D., and Wilson, A. 2012. Fuels characteristics of woods-run whole tree southern pine chips. Biomass Bioenergy 37: 67-72. 
Barnett, J.P., and Sheffield, R.M. 2004. Slash pine: Characteristics, history, status, and trends. In Slash Pine: Still Growing and Growing! Proceedings of the Slash Pine Symposium. Gen. Tech Report SRS-76. Edited by E.D. Dickens, J.P. Barnett, W.G. Hubbard, and E.J. Jokela. USDA Forest Service, Southern Research Station, Asheville, NC. pp. 1-6.

Bauer, G., Speck, T., Blömer, J., Bertling, J., and Speck, O. 2010. Insulation capacity of the bark of tree with different fire adaptation. J. Mat. Sci. 45: 5950-5959.

Borders, B.E., and Harrison, W.M. 1989. Comparison of slash pine and loblolly pine performance on cutover site-prepared sites in the coastal plain of Georgia and Florida. South. J. Appl. For. 13: 204-207.

Burkes, E.C., Will, R.E., Barron-Gafford, G.A., Teskey, R.O., and Shiver, B. 2003. Biomass partitioning and growth efficiency of intensively managed Pinus taeda and Pinus elliottii stands of different planting densities. For. Sci. 49(2): 224-234.

Chmura, D.J., Rahman, M.S., and Tjoelker, M.G. 2007. Crown structure and biomass allocation patterns modulate aboveground productivity in young loblolly and slash pine. For. Ecol. Manage. 243: 219-230.

Chmura, D.J., and Tjoelker, M.G. 2008. Leaf traits in relation to crown development, light interception and growth of elite families of loblolly and slash pine. Tree Physiol. 28: 729742. 
Clark III, A., and Saucier, J.R. 1991. Influence of planting density, intensive culture, geographic location, and species on juvenile wood formation in southern pine. Georgia Forest Research Paper 85: 1-13.

Colbert, S.R., Joekela, E.J., and Neary, D.G. 1990. Effects of annual fertilization and sustained weed control on dry matter partitioning, leaf area, and growth efficiency of juvenile loblolly and slash pine. For. Sci. 36(4): 995-1014.

Cole, D.E., Zobel, B.J., and Roberds, J.H. 1966. Slash, loblolly and longleaf pine in a mixed natural stand; A comparison of their wood properties, pulp yields, and paper properties. Tappi J. 49(4): 161-166.

Dalla-Tea, F., and Jokela, E.J. 1991. Needlefall, canopy light interception, and productivity of young intensively managed slash and loblolly pine stands. For. Sci. 37(5): 1298-1313.

Dipesh, K.C., Will, R.E., Lynch, T.B., Heinemann, R., and Holeman, R. 2015. Comparison of loblolly, shortleaf and pitch $\times$ loblolly pine plantations growing in Oklahoma. For. Sci. 61(3): 540-547.

Doruska, P.F., and Patterson, D.W. 2006. An individual-tree, merchantable stem, green weight equation for loblolly pine pulpwood in Arkansas, including seasonal effects. South J. Appl. For. 30(2): 61-65.

Eberhardt, T.L. 2012. Impact of industrial source on the chemical composition of loblolly pine bark. Forest Prod. J. 62(7/8): 516-519. 
Eberhardt, T.L. 2013. Longleaf pine inner bark and outer bark thicknesses: measurement and relevance. South J. Appl. For. 37(3): 177-180.

Eberhardt, T.L. 2015. Thickness and roughness measurements for air-dried longleaf pine bark. In Proceedings of the $17^{\text {th }}$ Biennial Southern Silvicultural Research Conference, e-Gen. Tech. Rep. No. 203. Edited by A.G. Holley, K.F. Connor, and J.D. Haywood. USDA Forest Service, Southern Research Station, Asheville, NC. 551 p.

Eberhardt, T.L., and Samuelson, L.J. 2015. Collection of wood quality data by X-ray densitometry: a case study with three southern pines. Wood Sci. Technol. 49: 739-753.

Forest Products Laboratory. 2010. Wood handbook: wood as an engineering material. General Technical Report FPL-GTR-190. USDA Forest Service, Forest Products Laboratory, Madison, WI. 508p.

Fox, T.R., Jokela, E.J., and Allen, H.L. 2007. The development of pine plantation silviculture in the southern United States. J. For. 105(7): 337-347.

Gonzalez-Benecke, C.A., Gezan, S.A., Albaugh, T.J., Allen, H.L., Burkhart, H.E., Fox, T.R., Jokela, E.J., Maier, C.A., Martin, T.A., Rubilar, R.A., and Samuelson, L.J. 2014. Local and general above-stump biomass functions for loblolly pine and slash pine trees. For. Ecol. Manage. 334: 254-276. 
Hanula, J.L., Franzreb, K.E., and Pepper, W.D. 2000. Longleaf pine characteristics associated with arthropods available for red-cockaded woodpeckers. J. Wildlife Manage. 64(1): 60-70.

Harder, M.L., and Einspahr, D.W. 1976. Bark fuel value of important pulpwood species. Tappi J. 59(12): 132.

Hardin, J.W., Leopold, D.J. and White, F.M. 2001. Harlow and Harrar's Textbook of Dendrology (9th ed.), McGraw Hill, 534 p.

Hare, R.C. 1965. Contribution of bark to fire resistance of southern trees. J. For. 63(4): 248251.

Haywood, J.D. 2000. Mulch and hexazinone herbicide shorten the time longleaf pine seedlings are in the grass stage and increase height growth. New Forests 19: 279-290.

Huggett, R., Wear, D.N., Li, R., Coulston, J., and Liu, S. 2013. Forest forecasts. In The Southern Forest Future Project: Technical Report. Gen. Tech. Rep. No. 178. Edited by D.N. Wear and J.G. Greis. USDA Forest Service, Southern Research Station, Asheville, NC. 542 p.

Jokela, E.J., and Martin, T.A. 2000. Effects of ontogeny and soil nutrient supply on production, allocation, and leaf area efficiency in loblolly and slash pine stands. Can. J. For. Res. 30: 1511-1524. 
Jordan, L., Clark III, A., Schimleck, L.R., Hall, D.B., and Daniels, R.F. 2008. Regional variation in wood specific gravity of planted loblolly pine in the United States. Can. J. For. Res. 38: 698-710.

Kahle, D., and Wickham, H. 2013. ggmap: Spatial Visualization with ggplot2. The R Journal 5(1):144-161.

Kuznetsova, A., Brockhoff, P.B., and Christensen, R.H.B. 2016. lmerTest: Tests in Linear Mixed Effects Models. R package version 2.0-33. https://CRAN.Rproject.org/package $=$ lmerTest

Laasasenaho, J., Melkas, T., and Aldén, S. 2005. Modelling bark thickness of Picea abies with taper curves. For. Ecol. Manage. 206: 35-47.

Martin, R.E. 1963. Thermal properties of wood. For. Prod. J. 13(10): 419-426.

Martin, R.E. 1969. Characterization of southern pine barks. For. Prod. J. 19(8): 23-30.

McKeand, S., Mullin, T., Byram, T., and White, T. 2003. Deployment of genetically improved loblolly and slash pines in the south. J. For. 4/5: 32-37.

Menges, E.S., and Deyrup, M.A. 2001. Postfire survival in south Florida slash pine: interacting effects of fire intensity, fire season, vegetation, burn size, and bark beetles. Int. J. Wildland Fire 10:53-62. 
Miles, P.D., and Smith, W.B. 2009. Specific gravity and other properties of wood and bark for the 156 tree species found in North America, Research Note NRS-38. USDA Forest Service, Northern Research Station, Newtown Square, PA. 35 p.

Monk, C.D. 1968. Successional and Environmental Relationships of the Forest Vegetation of North Central Florida. Am Midl. Nat. 79(2): 441-457.

Pausas, J.G. 2015. Fire regime and bark thickness. Funct. Ecol. 29: 315-327.

Phillips, D.R., Clark III, A., and Taras, M.A. 1976. Wood and bark properties of southern pine branches. Wood Sci. 8(3): 164-169.

R Core Team. 2016. R: A language and environment for statistical computing. R Foundation for Statistical Computing, Vienna, Austria. URL http://www.R-project.org/.

RStudio. 2016. RStudio: Integrated development environment for R. Boston, MA. https://www.rstudio.com/

Ratkowsky, D.A. 1990. Handbook of nonlinear regression models. Marcel Dekker, New York. 241 p.

Reifsnyder, W.E., Herrington, L.P., and Spalt, K.W. 1967. Thermophysical properties of bark on shortleaf, longleaf and red pine. Yale University School of Forestry Bulletin Number 70. 
Roth, B.E., Jokela, E.J., Martin, T.A., Huber, D.A., and White, T.L. 2007. Genotype $\times$ environment interactions in selected loblolly and slash pine plantations in the Southeastern United States. For. Ecol. Manage. 238: 175-188.

Samuelson, L.J., Stokes, T.A., and Johnsen, K.H. 2012. Ecophysiological comparison of 50year-old longleaf pine, slash pine and loblolly pine. For. Ecol. Manage. 274: 108-115.

Schultz, R.P. 1999. Loblolly - the pine for the twenty-first century. New Forests 17: 71-88.

Shiver, B.D., Rheney, J.W., and Hitch, K.L. 2000. Loblolly pine outperforms slash pine in Southeastern Georgia and Northern Florida. South J. Appl. For. 24(1): 31-36.

Stanturf, J.A., Wade, D.D., Waldrop, T.A., Kennard, D.K., and Archtemeier, G.L. 2002. In Southern Forest Resource Assessment. Gen. Tech Report SRS-53. Edited by D.M. Wear and J.G. Greis. USDA Forest Service, Southern Research Station, Asheville, NC. pp. 607-630.

Trockenbrodt, M. 1990. Survey and discussion of the terminology used in bark anatomy. IAWA Bull. 11(2): 141-166.

Vogel, J.G., Suau, L., Martin, T.A., and Jokela, E.J. 2011. Long term effects of weed control and fertilization on the carbon and nitrogen pools of a slash and loblolly pine forest in north central Florida. Can. J. For. Res. 41: 552-567.

Wang, G.G., and Wangen, S.R. 2011. Does frequent burning affect longleaf pine (Pinus palustris) bark thickness? Can. J. For. Res. 41: 1562-1565. 
Wear, D.N., and Greis, J.G. 2012. The Southern Forest Futures Project: Summary Report, Gen. Tech. Rep. No. 168, USDA Forest Service, Southern Research Station, Asheville, NC. $54 \mathrm{p}$.

Wickham, H., Francois, R. 2016. dplyr: A grammar of data manipulation. R package version 0.5.0. https://CRAN.R-project.org/package $=$ dplyr 
Table 1: Stand locations and characteristics.

\begin{tabular}{|c|c|c|c|c|c|c|c|c|}
\hline & & & & & DBH & cm) & Heigh & (m) \\
\hline Stand & Latitude & Longitude & Age & Species & Mean & SD & Mean & SD \\
\hline \multirow{2}{*}{1} & \multirow{2}{*}{31.4232} & \multirow{2}{*}{-81.8125} & \multirow{2}{*}{21} & Loblolly & 23.3 & 2.9 & 21.2 & 2.2 \\
\hline & & & & Slash & 21.5 & 0.5 & 20.9 & 0.2 \\
\hline \multirow{2}{*}{2} & \multirow{2}{*}{31.4232} & \multirow{2}{*}{-81.8125} & \multirow{2}{*}{21} & Loblolly & 18.9 & 4.1 & 19.5 & 0.2 \\
\hline & & & & Slash & 15.9 & 4.8 & 16.2 & 4.7 \\
\hline \multirow{2}{*}{3} & \multirow{2}{*}{30.6689} & \multirow{2}{*}{-81.6289} & \multirow{2}{*}{21} & Loblolly & 20.3 & 0.7 & 17.2 & 0.4 \\
\hline & & & & Slash & 23.1 & 3.9 & 19.7 & 0.3 \\
\hline \multirow[b]{2}{*}{4} & \multirow{2}{*}{30.5236} & \multirow{2}{*}{-81.9198} & \multirow{2}{*}{21} & Loblolly & 20.0 & 0.7 & 17.4 & 1.6 \\
\hline & & & & Slash & 22.1 & 2.0 & 18.9 & 0.4 \\
\hline \multirow{2}{*}{5} & \multirow{2}{*}{30.6725} & \multirow{2}{*}{-81.7643} & \multirow{2}{*}{21} & Loblolly & 23.9 & 5.8 & 20.5 & 1.0 \\
\hline & & & & Slash & 20.5 & 1.7 & 21.5 & 0.8 \\
\hline \multirow{2}{*}{6} & \multirow{2}{*}{30.7545} & \multirow{2}{*}{-81.8156} & \multirow{2}{*}{22} & Loblolly & 22.4 & 2.2 & 18.2 & 0.8 \\
\hline & & & & Slash & 25.5 & 3.2 & 21.1 & 1.5 \\
\hline \multirow{2}{*}{7} & \multirow{2}{*}{32.19529} & \multirow{2}{*}{-81.7040} & \multirow{2}{*}{22} & Loblolly & 17.4 & 2.0 & 15.8 & 1.2 \\
\hline & & & & Slash & 17.6 & 2.7 & 16.0 & 0.8 \\
\hline \multirow{2}{*}{8} & \multirow{2}{*}{30.48235} & \multirow{2}{*}{-82.02715} & \multirow{2}{*}{24} & Loblolly & 24.8 & 4.8 & 20.6 & 1.8 \\
\hline & & & & Slash & 16.4 & 1.3 & 17.2 & 1.6 \\
\hline \multirow{2}{*}{9} & \multirow{2}{*}{31.2576} & & & Loblolly & 19.3 & 1.3 & 19.0 & 1.0 \\
\hline & & -81.5479 & 22 & Slash & 20.0 & 1.6 & 20.1 & 0.3 \\
\hline 10 & 3102076 & -8157391 & 23 & Loblolly & 19.9 & 2.3 & 18.4 & 0.4 \\
\hline 10 & $31.029 / 6$ & $-81.5 / 391$ & 23 & Slash & 19.1 & 1.7 & 20.4 & 0.2 \\
\hline
\end{tabular}


Table 2. Comparison of overall wood and bark properties between loblolly pine and slash pines: whole-tree values based on disks taken along entire tree bole.

\begin{tabular}{|c|c|c|c|c|c|c|c|c|c|c|}
\hline & & \multicolumn{4}{|c|}{ Loblolly } & \multicolumn{4}{|c|}{ Slash } & \multirow[b]{2}{*}{$P$-value } \\
\hline Tissue & Property & Mean & $\mathrm{SD}$ & Min & Max & Mean & $\mathrm{SD}$ & Min & Max & \\
\hline \multirow{3}{*}{ Wood } & Specific Gravity & 0.498 & 0.022 & 0.447 & 0.548 & 0.523 & 0.029 & 0.475 & 0.572 & 0.0001 \\
\hline & $\begin{array}{l}\text { Moisture Content } \\
(\%)\end{array}$ & 106 & 9 & 93 & 128 & 96 & 10 & 78 & 120 & $<0.0001$ \\
\hline & $\begin{array}{l}\text { Green Weight } \\
\left(\mathrm{kg} \mathrm{m}^{-3}\right)\end{array}$ & 1026 & 25 & 974 & 1085 & 1023 & 32 & 922 & 1067 & 0.6425 \\
\hline \multirow{6}{*}{ Bark } & $\begin{array}{l}\text { Double Bark Thickness } \\
(\mathrm{cm})\end{array}$ & 0.88 & 0.18 & 0.67 & 1.45 & 0.90 & 0.20 & 0.57 & 1.35 & 0.7148 \\
\hline & Specific Gravity & 0.311 & 0.024 & 0.271 & 0.365 & 0.368 & 0.022 & 0.330 & 0.412 & $<0.0001$ \\
\hline & $\begin{array}{c}\text { Moisture Content } \\
(\%)\end{array}$ & 78 & 17 & 47 & 110 & 69 & 18 & 43 & 102 & 0.0007 \\
\hline & $\begin{array}{c}\text { Green Weight } \\
\left(\mathrm{kg} \mathrm{m}^{-3}\right) \\
\end{array}$ & 553 & 66 & 432 & 685 & 619 & 59 & 499 & 766 & $<0.0001$ \\
\hline & $\begin{array}{c}\text { Percent of Dry Mass } \\
(\%)\end{array}$ & 12.5 & 2.7 & 8.9 & 19.1 & 17.0 & 3.2 & 12.3 & 23.7 & $<0.0001$ \\
\hline & Percent of Green Volume $(\%)$ & 18.7 & 4.2 & 12.5 & 26.9 & 22.5 & 4.1 & 16.3 & 32.5 & $<0.0001$ \\
\hline \multirow{2}{*}{$\begin{array}{l}\text { Wood and } \\
\text { Bark }\end{array}$} & $\begin{array}{l}\text { Green Weight of Wood and Bark to Volume } \\
\qquad \begin{array}{c}\text { Wood } \\
\left(\mathrm{kg} \mathrm{m}^{-3}\right)\end{array}\end{array}$ & 1151 & 37 & 1072 & 1228 & 1202 & 53 & 1090 & 1304 & $<0.0001$ \\
\hline & $\begin{array}{l}\text { Green Weight of Wood and Bark to Volume } \\
\text { Wood and Bark } \\
\qquad\left(\mathrm{kg} \mathrm{m}^{-3}\right)\end{array}$ & 935 & 36 & 856 & 990 & 930 & 36 & 864 & 1003 & 0.5041 \\
\hline
\end{tabular}


Table 3: Comparison of stand-level values for wood and bark properties between loblolly pine and slash pines: whole-tree values based on disks taken along entire tree bole.

\begin{tabular}{|c|c|c|c|c|c|c|c|c|c|c|c|c|}
\hline & \multicolumn{12}{|c|}{ Tissue } \\
\hline & & \multicolumn{3}{|c|}{ Wood } & \multicolumn{6}{|c|}{ Bark } & \multicolumn{2}{|c|}{ Wood and Bark } \\
\hline Stand & Species & $\begin{array}{l}\text { Specific } \\
\text { Gravity }\end{array}$ & $\begin{array}{c}\text { Moisture } \\
\text { Content } \\
(\%)\end{array}$ & $\begin{array}{c}\text { Green } \\
\text { Weight } \\
\left(\mathrm{kg} \mathrm{m}^{-3}\right)\end{array}$ & $\begin{array}{c}\text { Double } \\
\text { Bark } \\
\text { Thickness } \\
\text { (cm) }\end{array}$ & $\begin{array}{l}\text { Specific } \\
\text { Gravity }\end{array}$ & $\begin{array}{c}\text { Moisture } \\
\text { Content } \\
(\%)\end{array}$ & $\begin{array}{c}\text { Green } \\
\text { Weight } \\
\left(\mathrm{kg} \mathrm{m}^{-3}\right)\end{array}$ & $\begin{array}{c}\text { Percent } \\
\text { of Dry } \\
\text { Mass } \\
(\%)\end{array}$ & $\begin{array}{c}\text { Percent } \\
\text { of Green } \\
\text { Volume } \\
(\%)\end{array}$ & $\begin{array}{c}\text { Green } \\
\text { Weight of } \\
\text { Wood and } \\
\text { Bark to } \\
\text { Volume } \\
\text { Wood } \\
\left(\mathrm{kg} \mathrm{m}^{-3}\right)\end{array}$ & $\begin{array}{c}\text { Green } \\
\text { Weight of } \\
\text { Wood and } \\
\text { Bark to } \\
\text { Volume } \\
\text { Wood and } \\
\text { Bark } \\
\left(\mathrm{kg} \mathrm{m}^{-3}\right)\end{array}$ \\
\hline \multirow{2}{*}{1} & Loblolly & 0.495 & 105 & 1014 & 0.91 & 0.284 & 88 & 535 & 11.3 & 18.2 & 1133 & 926 \\
\hline & Slash & 0.487 & 98 & 963 & 0.81 & 0.341 & 89 & 642 & 14.7 & 19.8 & 1122 & 900 \\
\hline \multirow{2}{*}{2} & Loblolly & 0.486 & 118 & 1060 & 0.79 & 0.322 & 87 & 600 & 12.8 & 18.1 & 1193 & 976 \\
\hline & Slash & 0.530 & 95 & 1033 & 0.82 & 0.346 & 76 & 609 & 17.7 & 24.7 & 1234 & 928 \\
\hline \multirow{2}{*}{3} & Loblolly & 0.513 & 103 & 1042 & 0.82 & 0.306 & 70 & 520 & 12.5 & 19.3 & 1166 & 940 \\
\hline & Slash & 0.531 & 97 & 1042 & 0.99 & 0.386 & 62 & 625 & 17.1 & 22.1 & 1220 & 950 \\
\hline \multirow{2}{*}{4} & Loblolly & 0.495 & 111 & 1043 & 1.18 & 0.289 & 61 & 466 & 15.7 & 24.0 & 1190 & 904 \\
\hline & Slash & 0.518 & 95 & 1006 & 1.13 & 0.364 & 45 & 527 & 19.6 & 25.6 & 1188 & 882 \\
\hline \multirow{2}{*}{5} & Loblolly & 0.506 & 106 & 1038 & 0.76 & 0.298 & 106 & 616 & 9.3 & 14.8 & 1145 & 975 \\
\hline & Slash & 0.537 & 93 & 1037 & 0.71 & 0.367 & 85 & 682 & 13.2 & 18.3 & 1188 & 971 \\
\hline \multirow{2}{*}{6} & Loblolly & 0.507 & 99 & 1009 & 0.85 & 0.322 & 81 & 584 & 11.9 & 17.5 & 1133 & 934 \\
\hline & Slash & 0.534 & 90 & 1011 & 1.18 & 0.376 & 66 & 623 & 17.9 & 23.5 & 1203 & 920 \\
\hline \multirow{2}{*}{7} & Loblolly & 0.507 & 102 & 1024 & 1.00 & 0.310 & 50 & 465 & 17.0 & 25.1 & 1179 & 884 \\
\hline & Slash & 0.541 & 93 & 1042 & 0.96 & 0.380 & 45 & 549 & 21.2 & 27.8 & 1252 & 903 \\
\hline \multirow{2}{*}{8} & Loblolly & 0.478 & 112 & 1010 & 0.76 & 0.336 & 83 & 616 & 10.6 & 14.5 & 1113 & 952 \\
\hline & Slash & 0.514 & 101 & 1033 & 0.83 & 0.377 & 60 & 600 & 18.0 & 23.0 & 1214 & 933 \\
\hline \multirow{2}{*}{9} & Loblolly & 0.497 & 106 & 1020 & 0.92 & 0.311 & 69 & 525 & 13.3 & 19.8 & 1150 & 921 \\
\hline & Slash & 0.523 & 96 & 1027 & 0.86 & 0.371 & 78 & 659 & 16.4 & 21.7 & 1212 & 947 \\
\hline \multirow{2}{*}{10} & Loblolly & 0.495 & 102 & 1000 & 0.79 & 0.331 & 84 & 607 & 11.0 & 15.7 & 1113 & 938 \\
\hline & Slash & 0.518 & 100 & 1035 & 0.68 & 0.374 & 80 & 674 & 14.1 & 18.5 & 1188 & 968 \\
\hline
\end{tabular}


Table 4. Comparison of wood and bark properties between loblolly pine and slash pine; whole-disk values based on disk taken at breast height alone.

\begin{tabular}{|c|c|c|c|c|c|c|c|c|c|c|}
\hline \multirow[b]{2}{*}{ Tissue } & \multirow[b]{2}{*}{ Property } & \multicolumn{4}{|c|}{ Loblolly } & \multicolumn{4}{|c|}{ Slash } & \multirow[b]{2}{*}{$P$-value } \\
\hline & & Mean & SD & Min & Max & Mean & SD & Min & Max & \\
\hline \multirow{3}{*}{ Wood } & Specific Gravity & 0.557 & 0.029 & 0.486 & 0.6 & 0.570 & 0.034 & 0.491 & 0.62 & 0.1151 \\
\hline & $\begin{array}{l}\text { Moisture Content } \\
(\%)\end{array}$ & 80 & 11 & 66 & 112 & 77 & 10 & 57 & 107 & 0.2576 \\
\hline & $\begin{array}{l}\text { Green Weight } \\
\left(\mathrm{kg} \mathrm{m}^{-3}\right)\end{array}$ & 1000 & 39 & 928 & 1077 & 1007 & 44 & 908 & 1082 & 0.4960 \\
\hline \multirow{6}{*}{ Bark } & $\begin{array}{l}\text { Double Bark Thickness } \\
(\mathrm{cm})\end{array}$ & 1.08 & 0.25 & 0.70 & 1.80 & 1.01 & 0.34 & 0.10 & 1.90 & 0.1896 \\
\hline & Specific Gravity & 0.295 & 0.029 & 0.244 & 0.368 & 0.364 & 0.031 & 0.318 & 0.426 & $<0.0001$ \\
\hline & $\begin{array}{c}\text { Moisture Content } \\
(\%)\end{array}$ & 52 & 16 & 26 & 89 & 53 & 16 & 30 & 82 & 0.8245 \\
\hline & $\begin{array}{c}\text { Green Weight } \\
\left(\mathrm{kg} \mathrm{m}^{-3}\right)\end{array}$ & 448 & 62 & 348 & 561 & 554 & 56 & 426 & 650 & $<0.0001$ \\
\hline & $\begin{array}{c}\text { Percent of Dry Mass } \\
(\%)\end{array}$ & 14.8 & 4.1 & 9.4 & 26.8 & 16.5 & 5.1 & 2.5 & 27.8 & 0.0645 \\
\hline & Percent of Green Volume (\%) & 24.6 & 5.7 & 15.6 & 39.1 & 23.6 & 7.0 & 3.1 & 41.2 & 0.4882 \\
\hline \multirow{2}{*}{$\begin{array}{l}\text { Wood and } \\
\text { Bark }\end{array}$} & $\begin{array}{c}\text { Green Weight of Wood and Bark to } \\
\text { Volume Wood } \\
\left(\mathrm{kg} \mathrm{m}^{-3}\right)\end{array}$ & 1147 & 68 & 1043 & 1292 & 1181 & 81 & 1036 & 1352 & 0.0336 \\
\hline & $\begin{array}{l}\text { Green Weight of Wood and Bark to } \\
\text { Volume Wood and Bark } \\
\left(\mathrm{kg} \mathrm{m}^{-3}\right)\end{array}$ & 863 & 47 & 762 & 956 & 897 & 48 & 795 & 1004 & 0.0011 \\
\hline
\end{tabular}


Table 5: Comparison of stand level values for wood and bark properties between loblolly pine and slash pines: whole-disk values based on disk taken at breast height alone.

\begin{tabular}{|c|c|c|c|c|c|c|c|c|c|c|c|c|}
\hline & & \multicolumn{11}{|c|}{ Tissue } \\
\hline & & \multicolumn{3}{|c|}{ Wood } & \multicolumn{6}{|c|}{ Bark } & \multicolumn{2}{|c|}{ Wood and Bark } \\
\hline Stand & Species & $\begin{array}{l}\text { Specific } \\
\text { Gravity }\end{array}$ & $\begin{array}{c}\text { Moisture } \\
\text { Content } \\
(\%)\end{array}$ & $\begin{array}{c}\text { Green } \\
\text { Weight } \\
\left(\mathrm{kg} \mathrm{m}^{-3}\right)\end{array}$ & $\begin{array}{l}\text { Double } \\
\text { Bark } \\
\text { Thickness } \\
(\mathrm{cm})\end{array}$ & $\begin{array}{l}\text { Specific } \\
\text { Gravity }\end{array}$ & $\begin{array}{c}\text { Moisture } \\
\text { Content } \\
(\%)\end{array}$ & $\begin{array}{c}\text { Green } \\
\text { Weight } \\
\left(\mathrm{kg} \mathrm{m}^{-3}\right)\end{array}$ & $\begin{array}{c}\text { Percent } \\
\text { of Dry } \\
\text { Mass } \\
(\%)\end{array}$ & $\begin{array}{l}\text { Percent } \\
\text { of Green } \\
\text { Volume } \\
(\%)\end{array}$ & $\begin{array}{c}\text { Green } \\
\text { Weight of } \\
\text { Wood and } \\
\text { Bark to } \\
\text { Volume } \\
\text { Wood } \\
\left(\mathrm{kg} \mathrm{m}^{-3}\right)\end{array}$ & $\begin{array}{c}\text { Green } \\
\text { Weight of } \\
\text { Wood and } \\
\text { Bark to } \\
\text { Volume } \\
\text { Wood and } \\
\text { Bark } \\
\left(\mathrm{kg} \mathrm{m}^{-3}\right)\end{array}$ \\
\hline \multirow{2}{*}{1} & Loblolly & 0.556 & 76 & 979 & 1.20 & 0.268 & 56 & 417 & 13.5 & 24.5 & 1115 & 841 \\
\hline & Slash & 0.526 & 77 & 931 & 0.97 & 0.328 & 75 & 574 & 15.4 & 22.6 & 1099 & 850 \\
\hline \multirow{2}{*}{2} & Loblolly & 0.560 & 84 & 1029 & 0.97 & 0.322 & 55 & 494 & 15.1 & 23.8 & 1186 & 902 \\
\hline & Slash & 0.568 & 77 & 1005 & 0.80 & 0.355 & 59 & 566 & 15.9 & 23.0 & 1179 & 905 \\
\hline \multirow{2}{*}{3} & Loblolly & 0.554 & 87 & 1038 & 1.07 & 0.292 & 54 & 451 & 14.9 & 24.9 & 1186 & 891 \\
\hline & Slash & 0.563 & 83 & 1026 & 1.13 & 0.388 & 46 & 564 & 17.6 & 23.7 & 1204 & 917 \\
\hline \multirow{2}{*}{4} & Loblolly & 0.543 & 94 & 1049 & 1.40 & 0.275 & 42 & 393 & 19.6 & 32.1 & 1233 & 835 \\
\hline & Slash & 0.568 & 75 & 995 & 1.27 & 0.356 & 36 & 486 & 18.7 & 26.9 & 1173 & 856 \\
\hline \multirow{2}{*}{5} & Loblolly & 0.570 & 76 & 998 & 1.00 & 0.279 & 64 & 457 & 11.1 & 20.4 & 1115 & 888 \\
\hline & Slash & 0.579 & 75 & 1013 & 0.73 & 0.362 & 65 & 596 & 11.5 & 17.2 & 1136 & 940 \\
\hline \multirow{2}{*}{6} & Loblolly & 0.567 & 69 & 959 & 0.87 & 0.285 & 55 & 442 & 10.2 & 18.5 & 1060 & 864 \\
\hline & Slash & 0.594 & 67 & 991 & 1.43 & 0.375 & 41 & 529 & 18.4 & 26.3 & 1181 & 869 \\
\hline \multirow{2}{*}{7} & Loblolly & 0.563 & 78 & 1001 & 1.30 & 0.300 & 41 & 422 & 20.7 & 32.8 & 1211 & 812 \\
\hline & Slash & 0.598 & 74 & 1040 & 1.33 & 0.369 & 33 & 490 & 24.9 & 35.1 & 1306 & 846 \\
\hline \multirow{2}{*}{8} & Loblolly & 0.552 & 81 & 1000 & 0.93 & 0.311 & 51 & 470 & 11.7 & 19.3 & 1110 & 895 \\
\hline & Slash & 0.555 & 89 & 1042 & 0.63 & 0.355 & 48 & 522 & 12.4 & 18.5 & 1169 & 940 \\
\hline \multirow{2}{*}{9} & Loblolly & 0.536 & 81 & 964 & 1.10 & 0.294 & 44 & 427 & 16.7 & 26.7 & 1122 & 821 \\
\hline & Slash & 0.577 & 75 & 1010 & 1.00 & 0.348 & 75 & 609 & 15.8 & 23.7 & 1201 & 914 \\
\hline \multirow{2}{*}{10} & Loblolly & 0.571 & 72 & 984 & 0.97 & 0.319 & 61 & 513 & 14.0 & 22.6 & 1134 & 878 \\
\hline & Slash & 0.573 & 77 & 1012 & 0.77 & 0.407 & 49 & 605 & 14.4 & 19.1 & 1157 & 935 \\
\hline
\end{tabular}




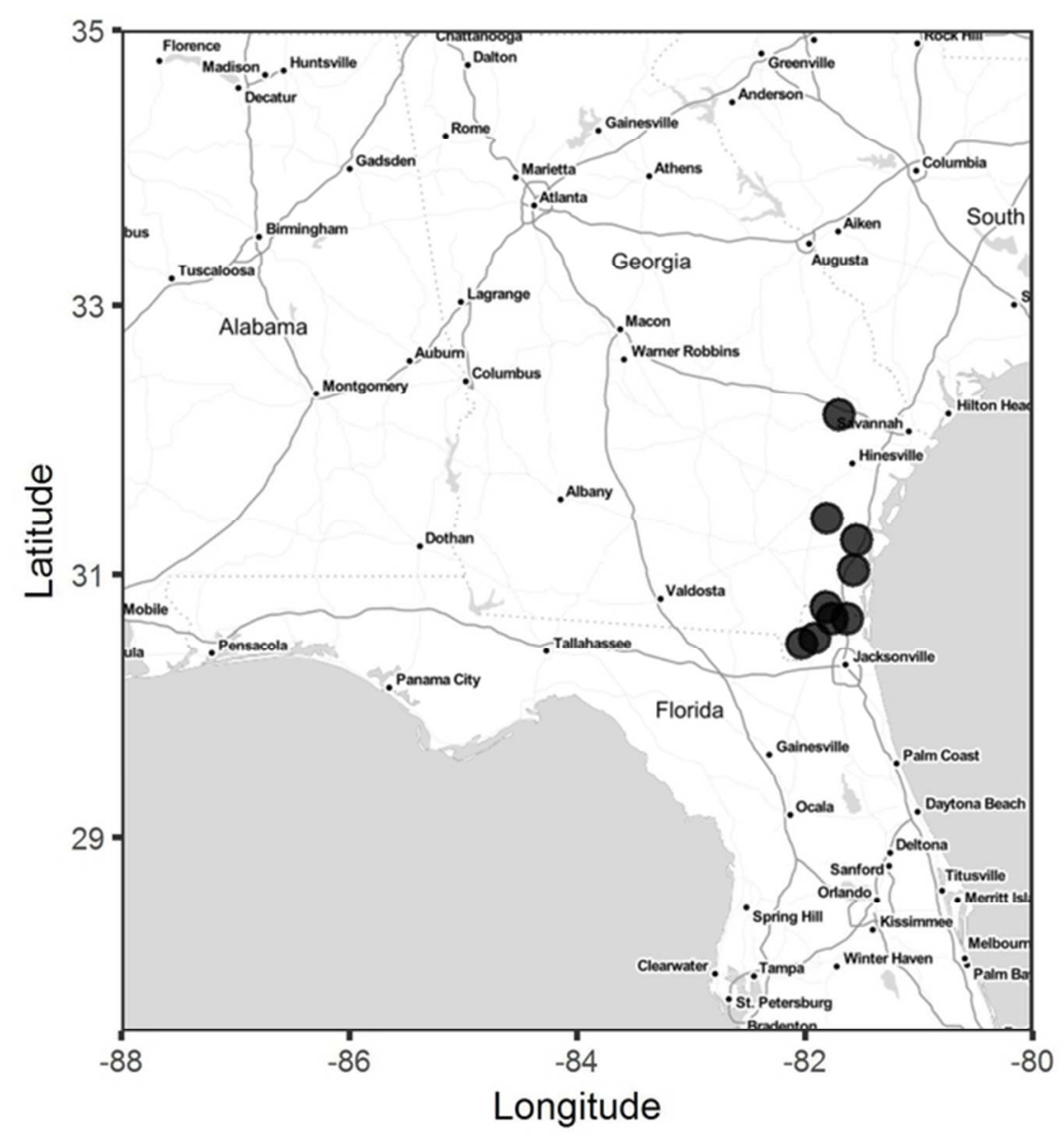

Figure 1: Map of stand locations for the study $63 \times 59 \mathrm{~mm}(300 \times 300$ DPI $)$ 

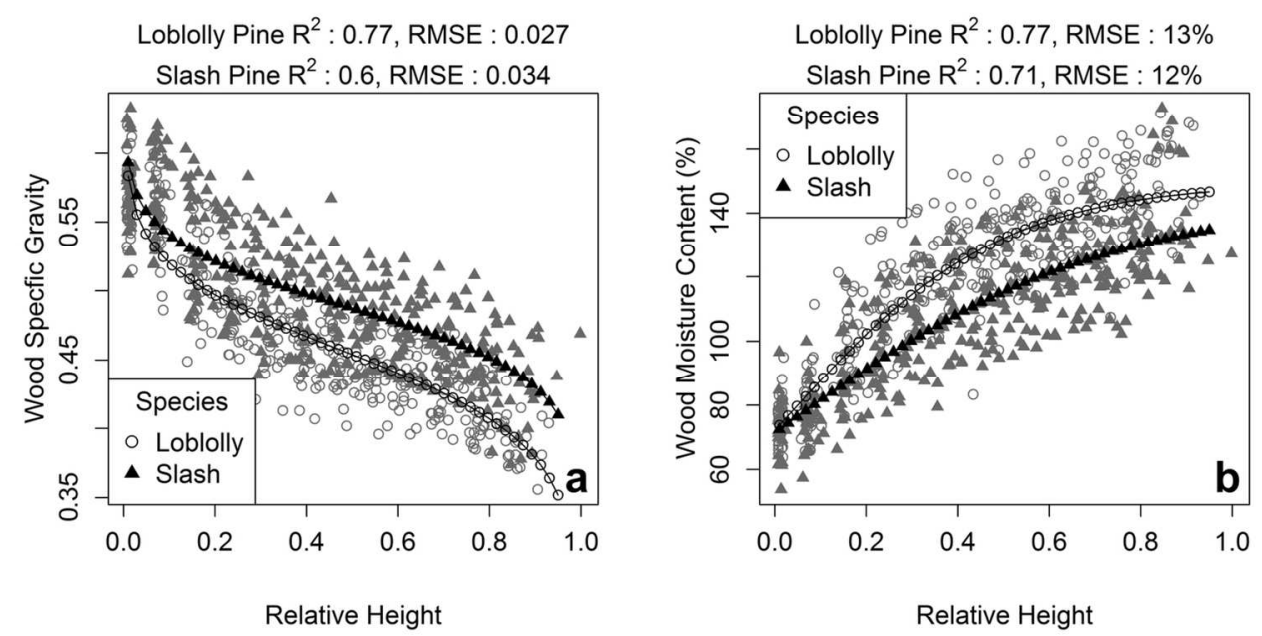

Figure 2: Wood specific gravity (a) and moisture content (b) plotted against relative height along tree bole. $127 \times 63 \mathrm{~mm}(300 \times 300 \mathrm{DPI})$ 

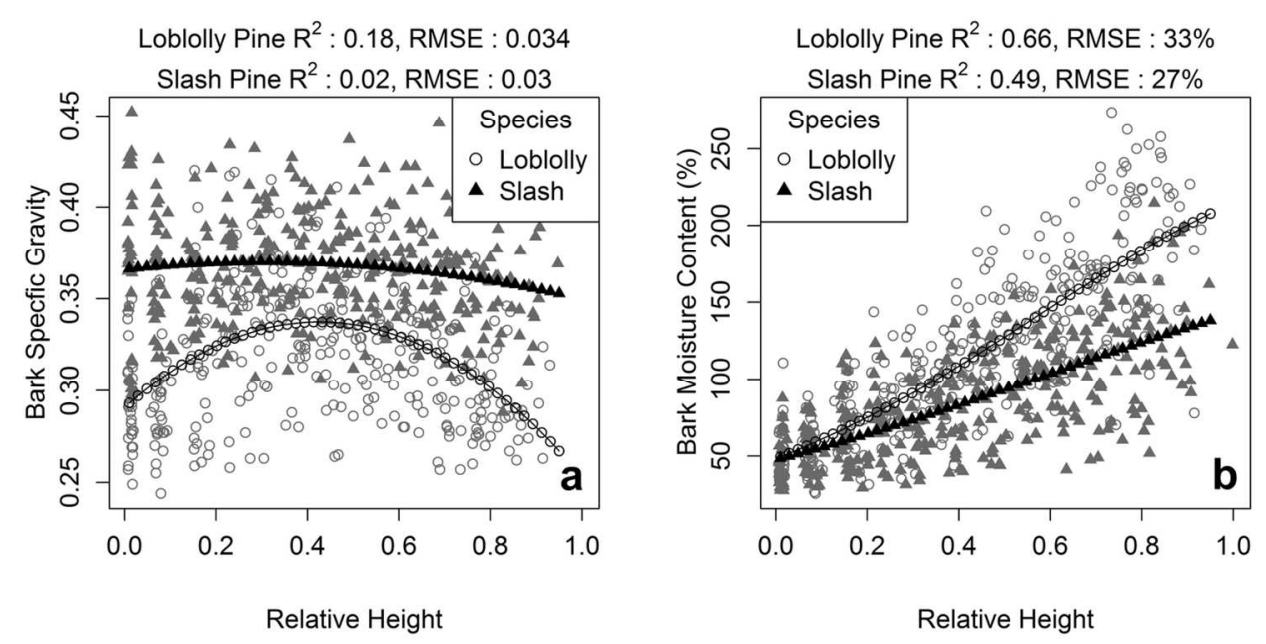

Figure 3: Bark specific gravity (a) and moisture content (b) plotted against relative height along tree bole. $127 \times 63 \mathrm{~mm}(300 \times 300 \mathrm{DPI})$ 


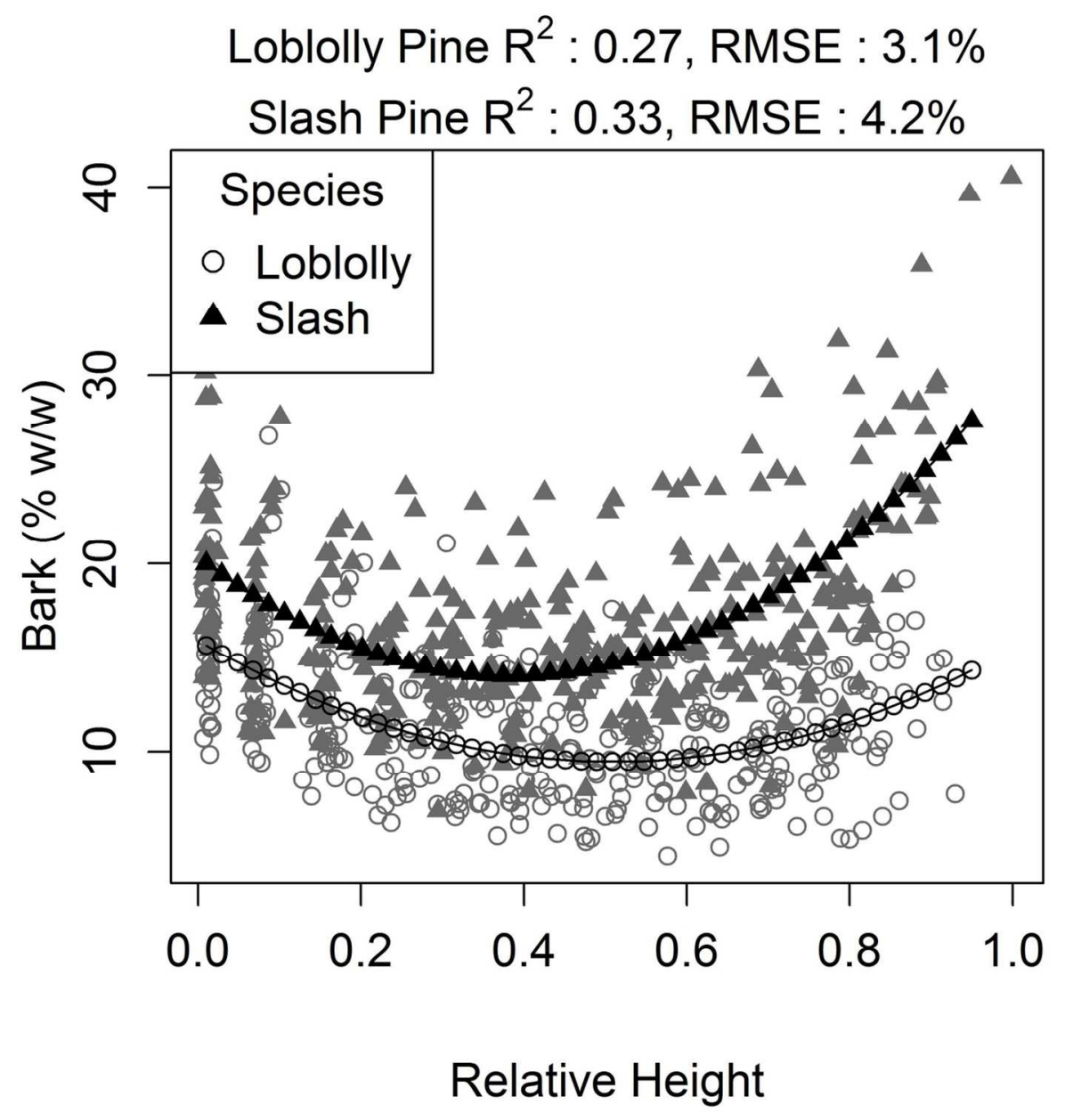

Figure 4: Percentage bark plotted against relative height along tree bole. $127 \times 127 \mathrm{~mm}(300 \times 300 \mathrm{DPI})$ 